\title{
EMBRIOGENESIS SOMATIK ANGGREK BULAN Phalaenopsis amabilis (L.) BI: STRUKTUR DAN POLA PERKEMBANGAN
}

\author{
Edy Setiti Wida Utami ${ }^{*}$, Issirep Soemardi ${ }^{* *}$, Taryono***, dan Endang Semiarti ${ }^{\star * * *}$ \\ * Laboratorium Biologi Reproduksi, Fakultas MIPA UNAIR \\ ** Laboratorium Anatomi Tumbuhan, Fakultas Biologi UGM \\ $* * *$ Laboratorium Kultur Jaringan Tumbuhan, Fakultas Pertanian UGM \\ $\star \star \star \star$ Laboratorium Kultur Jaringan Tumbuhan, Fakultas Biologi UGM
}

\begin{abstract}
Research of the structure and development pattern of somatic embryos from callus of leaf explants moon orchid Phalaenopsis amabilis $(L) B l$ had been done. One year old of plantlets were used as explants sources. Basal leaf of these explants were cultured in Somatic Embryo Induction Medium (SEIM) e.i.: NP(New Phalaenopsis) medium added with $2 \mathrm{mg} / \mathrm{L}$ NAA, $1 \mathrm{mg} / \mathrm{L} \mathrm{BA,} 10 \mathrm{~g} / \mathrm{L}$ sucrose, and $2 \mathrm{~g} / \mathrm{L}$ gellan gum. Then somatic embryos were transferred to EMM (Embryo Maturation Medium) e.i.: NP medium added with $1 \mathrm{mg} / \mathrm{L} \mathrm{NAA,} 1 \mathrm{mg} / \mathrm{L} \mathrm{BA}, 10 \mathrm{~g} / \mathrm{L}$ sucrose, and $2 \mathrm{~g} / \mathrm{L}$ gellan gum. Finally, mature somatic embryo were transferred to NP medium without plant growth regulator as Embryo Germination Medium (EGM). The origin of somatic embryos initially from single cell at the pheriphery of embryogenic callus. These cells then devided in mitotic repeatedly formed globular proembryo, elongation embryo, and completed embryo. The structure and development pattern of somatic embryos as the same as with zygotic embryo.
\end{abstract}

Key words: moon orchid, somatic embryogenesis, structure and developmental pattern, light microscopy

\section{PENGANTAR}

Embriogenesis somatik adalah suatu proses di mana sel-sel soma mengalami urutan perkembangan yang mirip dengan perkembangan embrio zigotik. Proses ini penting dalam teknik kultur in vitro (Merkle et al., 1990) dan dapat digunakan sebagai model dalam perkembangan embrio tumbuhan (Racuson dan Schiavone, 1990; Dudits et al., 1991). Secara morfologis embrio somatik hampir sama dengan embrio zigotik yaitu bipolar walaupun berkembang melalui cara yang berbeda (Arnold et al., 2002).

Pada Monocotyledoneae, embrio somatik tahap globular berkembang menjadi embrio yang mempunyai suspensor. Skutelum dibentuk pada bagian lateral dari embrio, primordia akar dan tunas berkembang pada bagian ujung-ujung aksis embrio. Skutelum kemudian berkembang menjadi kotiledon tunggal. Selanjutnya perkembangan embrio somatik secara morfologis dari tahap globular dan seterusnya mirip dengan perkembangan embrio zigotik (Tautorus et al., 1991 dalam Toonen dan de Vries, 1996).

Saat ini embrio somatik mandapat perhatian yang besar di bidang bioteknologi tanaman, yaitu untuk regenerasi tanaman transgenik dan produksi biji sintetik atau artificial seed (Brischia et al., 2002; Mamiya dan Sakamoto, 2001; Nieves et al., 2001; Sicurani et al., 2001). Untuk penyimpanan benih dalam jangka panjang maupun jangka pendek, embrio somatik dianggap sebagai bahan yang ideal untuk disimpan, mengingat strukturnya yang bipolar sehingga selalu siap dikecambahkan untuk menghasilkan benih somatik (Bajaj, 1995a; 1995b). Aplikasi embrio somatik selain untuk mikropropagasi dan untuk pelestarian plasma nutfah, dapat juga digunakan untuk mendukung program pemuliaan tanaman. Melalui DNA rekombinan, penggunaan struktur embrio somatik lebih disukai karena tanaman berasal dari 1 sel, sehingga akan memberikan hasil yang lebih tinggi dengan mengurangi terjadinya chimera (Bajaj, 1995a; Ellis, 1995).

Seperti diketahui bahwa organisme hidup memiliki urutan proses perkembangan pada bagian-bagian penyusunnya, demikian pula embrio tumbuhan juga mengalami perubahan-perubahan yang khas selama perkembangannya. Perubahan-perubahan yang menandai selama embriogenesis antara lain perubahan pada struktur anatomis, morfologis dan pola perkembangan embrio (Arnold et al., 2002). Meskipun embriogenesis somatik pada anggrek bulan Ph amabilis telah banyak diteliti, tetapi informasi tentang struktur dan pola perkembangan embrio anggrek bulan tersebut belum ada informasi. Kuo et al., (2005) hanya meneliti pengaruh berbagai konsentrasi 2,4dichlorophenoxyacetic acid (2,4-D), furfurylaminopurine (kinetin), N6-benzyladenine (BA), dan thidiazuron (TDZ) untuk regenerasi anggrek Phalaenopsis "Little Steve". Embriogenesis somatik langsung dan histologi embrio somatik Ph amabilis var. formosa shimadzu telah diteliti oleh Chen dan Chang (2004 dan 2006) namun demikian penelitian tersebut belum menjelaskan struktur embrio pada setiap tahap perkembangannya. Tokuhara dan 
Mii (2003) telah meneliti pola perkembangan embrio Phalaenopsis Snow Parade dari stadium globular sampai stadium berkecambah, sedangkan tahap sebelumnya tidak dijelaskan.

Berdasarkan uraian di atas, penelitian ini bertujuan untuk mengetahui struktur dan pola perkembangan embrio (embriogenesis) somatik anggrek bulan spesies $P$ h amabilis (L) Bl. secara in vitro.

\section{BAHAN DAN CARA KERJA}

\section{Bahan Penelitian}

Dalam penelitian ini digunakan tanaman anggrek bulan Ph amabilis (L.) Bl yang diperoleh dari Pusat Anggrek Royal Orchid, Prigen, Jawa Timur. Eksplan yang dipakai adalah bagian pangkal helaian daun nomor 2 dari pucuk. Sebagai sumber eksplan adalah plantlet hasil kultur in vitro biji umur 12 bulan. Bahan-bahan kimia penyusun medium New Phalaenopsis (NP), zat pengatur tumbuh $\alpha$ Naphthalenacetic Acid (NAA), Benzyle Adenine (BA) dan bahan untuk pembuatan preparat histologis.

\section{Cara Kerja}

\section{Pembentukan plantlet}

Biji berumur 4 bulan hasil penyerbukan dikulturkan secara aseptis di atas medium NP padat, ditambah $100 \mathrm{~g} / \mathrm{L}$ ekstrak tomat dan $20 \mathrm{~g} / \mathrm{L}$ sukrosa tanpa zat pengatur tumbuh. Kultur diinkubasi pada suhu $23 \pm 1{ }^{\circ} \mathrm{C}$ dengan intensitas cahaya 3000 lux. Kecambah (seedling) dari biji umur 2 bulan dikulturkan ke medium NP cair, ditambah $1 \mathrm{mg} / \mathrm{L}$ BA, $0,5 \mathrm{mg} / \mathrm{L}$ NAA dan $5 \mathrm{~g} / \mathrm{L}$ sukrosa, selanjutnya diletakkan di atas shaker dengan kecepatan $80 \mathrm{rpm}$. Setiap bulan kecambah dipindah ke dalam medium NP cair yang baru, setelah 3 bulan dipindahkan ke medium NP padat ditambah $150 \mathrm{ml} / \mathrm{L}$ air kelapa, $20 \mathrm{~g} / \mathrm{L}$ sukrosa dan $1 \mathrm{~g} / \mathrm{L}$ arang aktif selama 7 bulan. Plantlet yang terbentuk dengan 4 daun selanjutnya digunakan sebagai sumber eksplan.

\section{Induksi pembentukan embrio somatik}

Bagian pangkal daun nomor 2 dari pucuk plantlet umur 12 bulan dipotong $(1-1,5 \mathrm{~cm})$ secara aseptis dan digunakan sebagai bahan eksplan. Eksplan tersebut ditanam dalam botol kultur yang berisi medium induksi embrio somatik (MIES) terdiri atas medium NP ditambah $2 \mathrm{mg} / \mathrm{L}$ NAA, $1 \mathrm{mg} / \mathrm{L}$ BA, $10 \mathrm{~g} / \mathrm{L}$ sukrose, dan $2 \mathrm{~g} / \mathrm{L}$ gellan gum. Kultur diinkubasi pada suhu $23 \pm 1{ }^{\circ} \mathrm{C}$ dengan intensitas cahaya 3000 lux. Kultur dipindah pada medium yang sama setiap 2 minggu sekali dan diamati perkembangannya. Pengamatan terhadap pembentukan embrio somatik dilakukan secara rutin seminggu sekali menggunakan mikroskop stereo.

\section{Maturasi embrio somatik}

Embrio somatik selanjutnya dipindah ke medium maturasi embrio (MME) yaitu medium NP ditambah 0,1 mg/L NAA, $1 \mathrm{mg} / \mathrm{L}$ BA, $10 \mathrm{~g} / \mathrm{L}$ sukrose, dan $2 \mathrm{~g} / \mathrm{L}$ gellan gum. Pengamatan terhadap perkembangan embrio dilakukan setiap seminggu sekali menggunakan mikroskop stereo.

\section{Perkecambahan embrio somatik}

Embrio somatik matang selanjutnya dipindah ke medium perkecambahan embrio (MPE) yaitu medium NP ditambah $20 \mathrm{~g} / \mathrm{L}$ sukrose, dan $2 \mathrm{~g} / \mathrm{L}$ gellan gum tanpa zat pengatur tumbuh. Pengamatan terhadap perkecambahan embrio dilakukan setiap seminggu sekali menggunakan mikroskop stereo.

\section{Pembuatan preparat histologis embrio somatik dari kalus}

Untuk mengamati perkembangan embrio somatik dibuat sediaan awetan dengan menggunakan metode parafin, pewarnaan ganda Safranin 1\% dan Fast Green 1\% dalam alkohol menurut Jensen (1962).

\section{HASIL}

Sampai enam minggu lamanya kalus tetap dipertahankan dalam medium yang sama (MIES) dan diamati perkembangannya. Pada minggu pertama pembentukan dan pertumbuhan kalus dimulai dari daerah luka bekas irisan, kalus tampak bening, berdinding tipis dan berbutirbutir (Gambar 1.A.). Selama 1 minggu dikultur, kalus terus membelah dan meluas sampai akhirnya pada minggu kedua menutupi seluruh bekas irisan. Pada minggu keempat kalus mengadakan proliferasi dan segera berubah warna menjadi hijau kekuningan, remah, dan tampak mengkilat (Gambar 1.B.), bersifat sangat embriogenik. Selanjutnya pada minggu ke-5-6 terbentuk embrio somatik globular. Embrio globular muncul sebagai tonjolan-tonjolan di atas permukaan kalus embriogenik (Gambar 1.C.).

Setelah dipindah pada MME, pada bagian dorsal embrio muncul takik sebagai tempat keluarnya daun dan rambut akar muncul pada permukaan embrio (Gambar 1.D.). Embrio somatik matang kemudian dipindah ke dalam MPE, yaitu media NP tanpa zat pengatur tumbuh. Dua minggu setelah dikultur pada medium itu, embrio memanjang (Gambar 1.E.), selanjutnya embrio tersebut berkecambah, 

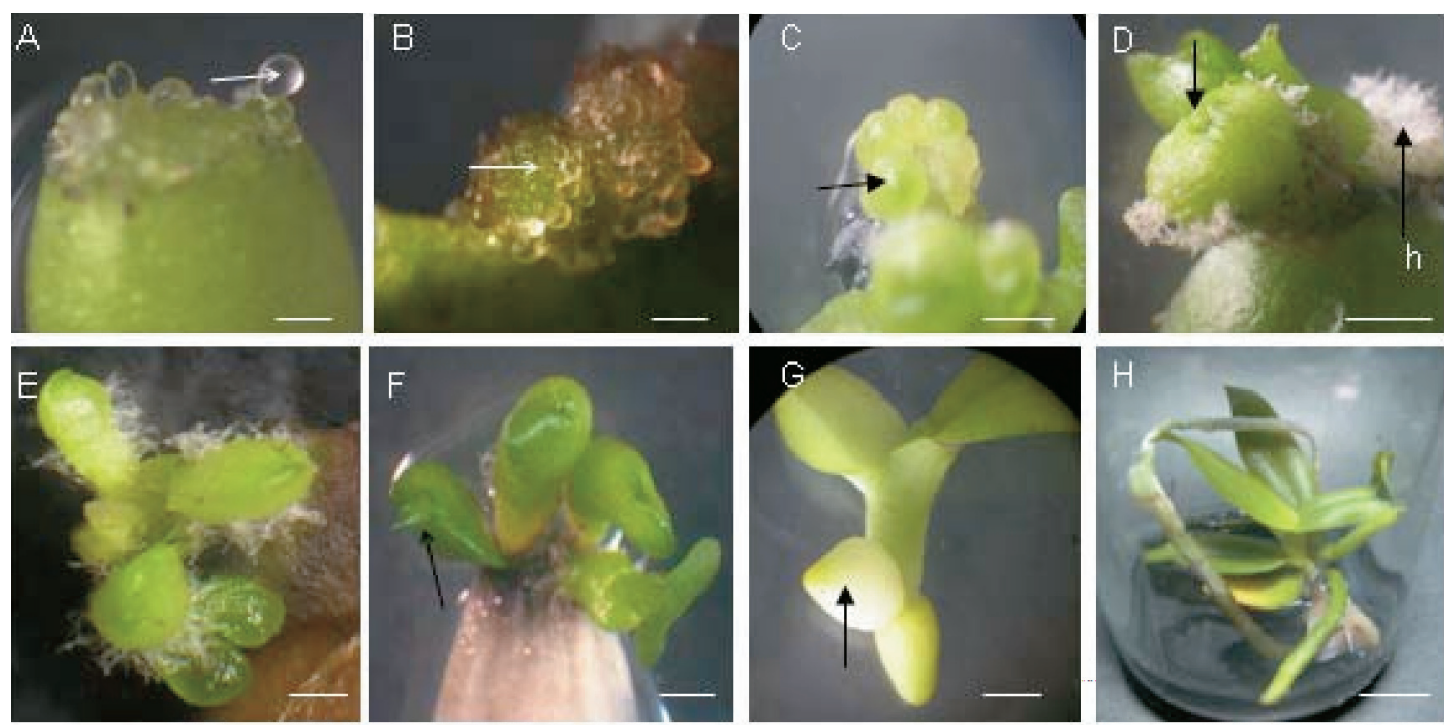

Gambar 1. Perkembangan embrio somatik anggrek bulan Ph amabilis (L.) Bl. secara in vitro. A. Pembentukan kalus (panah) pada daerah luka bekas irisan 1 minggu setelah dikultur pada MIES (Bar $=2 \mathrm{~mm}$ ). B. Kalus embriogenik (panah) 4 minggu setelah dikultur pada MIES (Bar $=2 \mathrm{~mm})$. C. Pembentukan embrio globular (panah) pada miggu ke-6 setelah dikultur pada MIES $($ Bar $=2 \mathrm{~mm})$. D. Embrio dengan takik (panah) di bagian dorsal dan rambut akar (h), 2-3 minggu setelah dikultur pada MME (Bar = $1 \mathrm{~mm}$ ). E. Embrio memanjang setelah 2 minggu dikultur di dalam MPE (Bar $=3 \mathrm{~mm})$. F. Embrio berkecambah setelah 3 minggu dikultur di dalam MPE, ini ditunjukkan dengan munculnya daun (panah) (Bar $=3 \mathrm{~mm}$ ). G. Akar (panah) muncul setelah embrio berkecambah dan menghasikan 2 daun setelah minggu ke-7 kultur (Bar $=2 \mathrm{~mm}$ ). $\mathrm{H}$. Plantlet hasil regenerasi dari embrio somatik setelah $18 \mathrm{minggu}$ di dalam MPE (Bar $=4 \mathrm{~mm})$.

yaitu dengan munculnya daun pertama setelah 3 minggu dikultur (Gambar 1.F.). Akar muncul setelah embrio berkecambah dan menghasilkan 2 daun setelah minggu ke-7 kultur (Gambar 1.G.), diasumsikan bahwa hormon endogen mempunyai peran dalam perkecambahan embrio.

Embrio somatik yang tumbuh di permukaan kalus memiliki tunas yang tumbuh dengan sempurna, hal ini dapat dijelaskan karena embrioid masih memiliki hubungan seluler dengan kalus pendukungnya melalui struktur seperti suspensor.

Pengamatan terhadap potongan melintang kalus embriogenik tampak tersusun dari sel-sel berukuran kecil, mempunyai inti yang jelas, sitoplasma padat (Gambar 2.A.). Selanjutnya sel embriogenik mengalami pembelahan berulang-ulang menghasilkan proembrio $2 \mathrm{sel}, 3 \mathrm{sel}, 5 \mathrm{sel}$ (Gambar 2.B., 2.C. dan 2.D.) dan seterusnya menjadi embrio bentuk globular yang tersusun dari sel-sel yang relatif sama (Gambar 2.E.). Perkembangan selanjutnya terjadi diferensiasi pada embrio, tampak di bagian apikal embrio tersusun dari sel-sel yang berukuran kecil dan di bagian basal tersusun dari sel-sel yang berukuran lebih besar (Gambar 2.F.). Selanjutnya embrio globular memanjang diikuti terbentuknya struktur seperti suspensor pada bagian basal embrio (Gambar 2.G.). Pada perkembangan selanjutnya terbentuk tonjolan pertama yang kemudian menjadi struktur yang menyerupai jambul dan diikuti terbentuknya tonjolan kedua, sehingga di antara dua tonjolan tersebut terbentuk takik (Gambar 2.H. dan 2.I.). Dari takik tersebut muncul tunas pucuk dan primordia daun (Gambar 2.J. dan 2.K.).

\section{PEMBAHASAN}

Pengamatan terhadap irisan melintang kalus embriogenik anggrek bulan, tampak embrio somatik terinisiasi dari multiplikasi sel-sel embriogenik yang ada di bagian perifer/tepi kalus. Ini ditunjukkan oleh sel-sel yang ada di bagian tepi kalus tersusun dari sel-sel berukuran kecil, mempunyai inti yang jelas, sitoplasma padat, menyerap warna kuat (Gambar 2.A.), dan adanya butir-bitir tepung (panah) (Gambar 2.B.), di mana ciri-ciri sel demikian ini dimiliki oleh sel-sel embriogenik atau meristematik (Taylor dan Vasil, 1996) serta memiliki regenerasi yang tinggi. Pola perkembangan seperti ini dilaporkan juga terjadi pada Saccharum officinarum (Ho dan Vasil, 1983 dalam Toonen dan de Vries, 1996). Selsel embriogenik selanjutnya membentuk kelompok/kluster sel-sel embriogenik dan diikuti pembelahan dengan arah transversal terhadap aksis panjang embrio sehingga dihasilkan proembrio 2 sel yang tidak sama besar, sel apikal (kecil) dan sel basal (lebih besar) mengandung butir-butir 

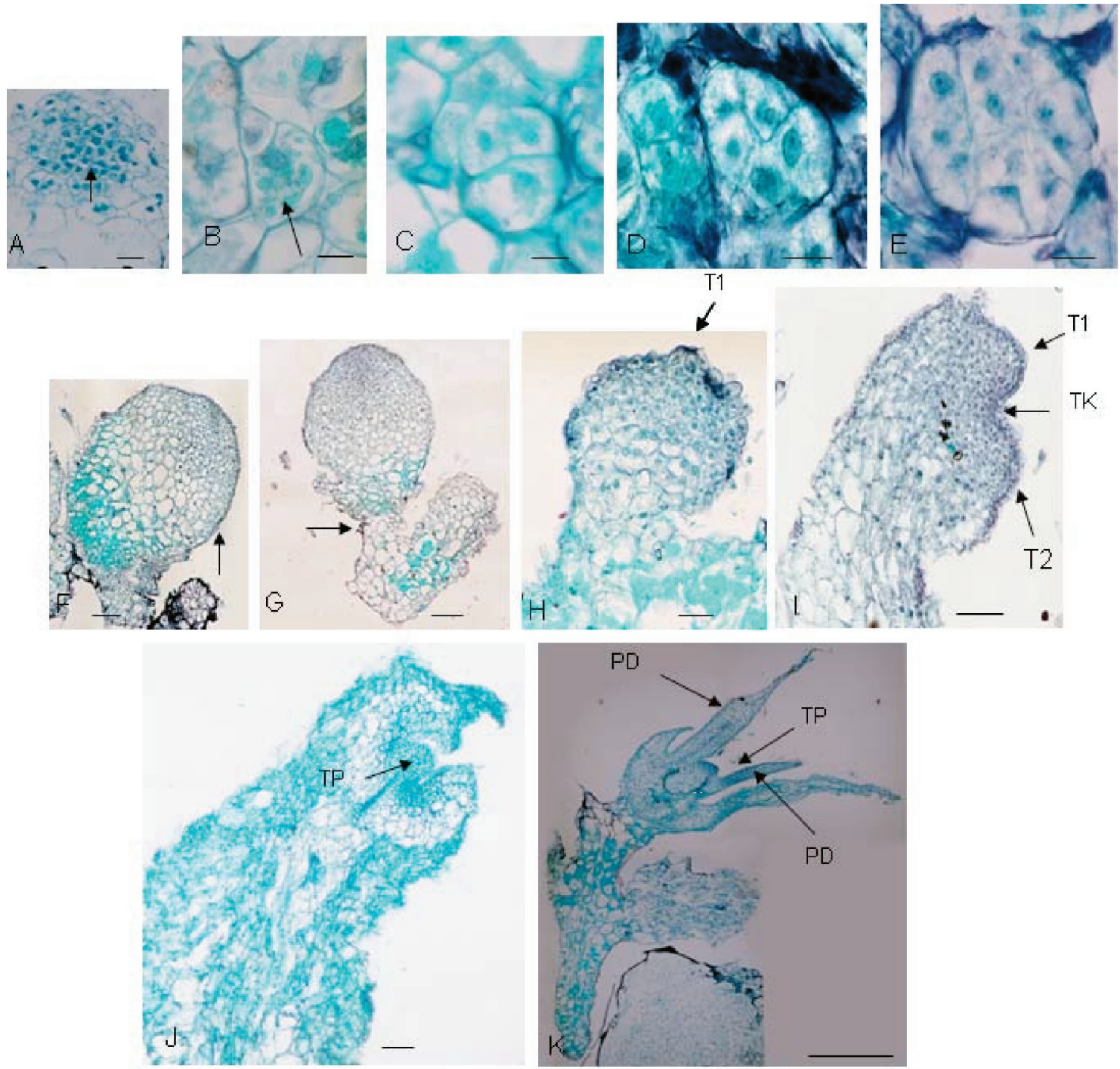

Gambar 2. Gambaran histologis perkembangan embrio somatik Ph amabilis (L.) BI. A. sel-sel embriogenik berukuran kecil, mempunyai inti yang jelas, menyerap warna kuat, sitoplasma padat (panah) (Bar $=68 \mu \mathrm{m}) \mathrm{B}$. Proembrio 2 sel, tersusun asimetris, sel basal lebih besar, mengandung butir-butir tepung (panah) (Bar $=20 \mu \mathrm{m})$. C. Proembrio 3 sel (Bar $=13 \mu \mathrm{m})$. D. Proembrio 5 sel (Bar $=45 \mu \mathrm{m})$. E. Fase globular, tersusun dari sel-sel yang relatif sama $(B a r=30 \mu \mathrm{m})$. F. Fase globular, tampak di bagian apikal tersusun dari selsel yang berukuran kecil dan di bagian basal tersusun dari sel-sel yang berukuran besar dan di bagian luarnya terdiri dari selapis sel tersusun teratur (panah). (Bar $=36 \mu \mathrm{m}$ ). G. Embrio globular memanjang dengan struktur seperti suspensor (panah) pada bagian basal embrio $(B a r=66 \mu \mathrm{m})$. H. Bagian apikal embrio terbentuk tonjolan (T1) (Bar $=41 \mu \mathrm{m})$. I. Terbentuk tonjolan ke-dua (T2) dan takik (TK) $($ Bar $=39 \mu \mathrm{m})$. J. Embrio dengan tunas pucuk di antara 2 tonjolan (Bar $=44 \mu \mathrm{m})$. K. Embrio berkecambah setelah 4 minggu dikultur pada MPE $($ Bar $=93 \mu \mathrm{m})$. ( TP = Tunas pucuk; PD = Primordia Daun; TK=Takik; T1 = Tonjolan pertama; $\mathrm{T} 2=$ Tonjolan ke-dua $)$.

tepung (Gambar 2.B.). Pola perkembangan embrio seperti ini terjadi pada kebanyakan embrio zigotik anggrek (Arditti, 1992). Selanjutnya terjadi pembelahan secara cepat dari proembrio tersebut, menghasilkan proembrio 3 sel dan 5 sel (Gambar 2.C. dan 2.D.), kemudian embrio fase globular yang tersusun dari sel-sel yang relatif sama (Gambar 2.E.). Selanjutnya terjadi diferensiasi pada embrio tersebut.
Bagian apikal embrio tersusun oleh sel-sel yang berukuran kecil dan aktif mengadakan pembelahan, sedangkan di bagian basal sel-selnya hanya membesar dan di bagian luarnya terdiri atas selapis sel yang tersusun teratur (Gambar 2.F.). Keadaan ini dapat disebabkan karena dalam medium terkandung sitokinin yang berupa BA, dengan konsentrasi dan kombinasi bersama zat pengatur tumbuh NAA mampu 
menginduksi pembentukan embrioid secara langsung dari kalus. Sitokinin diketahui berperan dalam memacu pembelahan sel.

Embrio somatik bentuk globular selanjutnya tumbuh memanjang dan membentuk struktur yang menyerupai suspensor pada bagian basalnya (Gambar 2.G.). Ini mengindikasikan bahwa embrio somatik yang terbentuk berasal dari sel tunggal, seperti yang disampaikan William dan Maheswaran (dalam Lee, 1997). Mereka menyatakan bahwa struktur basal dari embrioid dapat mengungkapkan asal mula suatu embrioid, yaitu embrio yang berasal dari sel tunggal memiliki suatu struktur yang menyerupai suspensor pada bagian basalnya dan sudah ditentukan sejak pembelahan awal. Embrio somatik Pennisetum americanum juga mempunyai struktur yang menyerupai suspensor yang menghubungkan embrio dengan kalus pendukungnya (Botti dan Vasil, 1984 dan Vasil dan Vasil, 1982 dalam Toonen dan de Vries, 1996). Fungsi suspensor terutama pada tahap awal embriogenesis adalah untuk transpor nutrisi bagi embrio (Steeves dan Sussex, 1989).

Pada perkembangan embrio selanjutnya, tampak adanya tonjolan (Gambar 2.H.), tonjolan pertama tersebut kemudian menjadi struktur seperti punggung dorsal atau menyerupai jambul yang melindungi bagian dorsal embrio. Selanjutnya terbentuk tonjolan kedua berseberangan dengan tonjolan pertama dan di antara dua tonjolan tersebut terdapat takik (Gambar 2.I.), sehingga nantinya akan dihasilkan perkecambahan ke arah atas (dorsiventral) (Gambar 1.F.). Pada embrio matang, sebelum berkecambah pada takik terbentuk tunas pucuk (Gambar 2.J.). Perkembangan selanjutnya adalah pada bagian kutub plumula dari embrio terbentuk tunas pucuk dan primordia daun (Gambar 2.K.) dan belum ditemukan adanya primordia akar. Hal ini menunjukkan bahwa pada anggrek bulan bagian dari embrio somatik yang aktif adalah kutub plumula. Bhojwani dan Bhatnagar (1981), menyatakan bahwa embrio zigotik pada anggrek bersifat monopolar dan seluruh kecambah berasal dari aktivitas kutub plumula dari embrio. Demikian pula Batygina dan Vasilyeva (1983), menyatakan bagian basal embrio anggrek tidak membentuk meristem akar. Akar anggrek adalah akar adventif dan muncul setelah diferensiasi tunas. Walaupun tidak ditemukan primordia akar, namun embrio somatik masih mempunyai hubungan seluler dengan kalus pendukungnya melaui struktur seperti suspensor sehingga embrio dapat tumbuh dan berkembang.

Berdasarkan hasil pengamatan pada embrio somatik anggrek bulan Ph amabilis (L.) ditemukan adanya tonjolan yang strukturnya mirip dengan tonjolan pada embrio zigotik Triticum sp. (Gramineae). Tonjolan tersebut pada Triticum sp. kemudian berkembang menjadi skutelum (Bhojwani dan Bhatnagar, 1981), sehingga tonjolan pada embrio somatik tersebut diperkirakan sebagai skutelum seperti pada Triticum sp.

Pengamatan secara morfologis menunjukkan fenomena bahwa akar muncul setelah daun pertama dan kedua berkembang. Dari data hasil penelitian dapat disimpulkan bahwa berdasarkan strukturnya embrio somatik anggrek bulan Ph. amabilis (L.) Bl mempunyai kutub plumula yang tersusun dari tunas pucuk dan primordia daun, dan akar adventif muncul setelah daun pertama dan kedua berkembang. Pola perkembangan embrio somatik anggrek bulan Ph. amabilis (L.) Bl dimulai dengan pembelahan sel tunggal di bagian perifer kalus embriogenik dengan arah transversal terhadap aksis panjang embrio membentuk proembrio 2 sel yang tidak sama besar dan seterusnya menjadi embrio globular, embrio memanjang, dan embrio yang lengkap pada setiap berkecambah

\section{KEPUSTAKAAN}

Arditti J, 1992. Fundamental of Orchid Biology. John Willey \& Sons, Inc., New York, 550-556.

Arnold SV, Sabala I, Bozhlov P, Dyachok J, dan Filonova L, 2002. Developmental Pathway of Somatic Embryogenesis. Plant Cell, Tissue and Organ Culture. 69: 233-249.

Bajaj YPS, 1995a. Somatic Embryogenesis and its Applications for Crop Improvement dalam Bajaj YPS. (Ed.) Biotechnology in Agriculture and Forestry. Springer-Verlag Berlin Heidenberg New York,105-118.

Bajaj YPS, 1995b. Cryopreservation of Somatic Embryos dalam Bajaj YPS (Ed.) Biotechnology in Agriculture and Forestry. Springer-Verlag Berlin Heidenberg New York, 221-227.

Batygina TB dan Vasilyeva VE, 1983. Development of the Embryo and Seedling of Some Orchids. Abstracts of the II All-Union Conference" Conservation and Cultivation of Orchids."Kiev, USSR, 73-75.

Bhojwani SS, dan Bhatnagar SP, 1981. The Embryology of Angiosperms. Vikas Publishing House Ltd., New Delhi, 171.

Brischia R, Piccioni E, dan Standardi A, 2002. Micropropagation and Synthetic Seed in M.26 Apple Rootstock (II): A. New Protocol for Production of Encapsulated Differentiating Propagules. Plant Cell, Tissue and Organ culture. 68: 137-141.

Chen JT dan Chang WC, 2006. Direct Somatic Embryogenesis and Plant Regeneration from Leaf Explants of Phalaenopsis amabilis var. formosa. Biologia Plantarum. 50(2): 169-173.

Chen JT, dan Chang WC, 2004. Induction of Repetitive Embryogenesis from Seed Derived Protocorms of Phalaenopsis amabilis var. formosa shimadzu. In Vitro Cellular and Development Biology Plant. 40: 290-293. 
Dudits D, Bogre L, dan Gyorgyey J, 1991. Molecular and Cellular Approaches to the Analysis of Plant Embryo Development from Somatic Cells In Vitro. J. Cell Sci. 99: 475.

Ellis D, 1995. Genetic Transformation of Somatic Embryos dalam Bajaj YPS (Ed.) Biotechnology in Agriculture and Forestry. Springer-Verlag Berlin Heidenberg New York, 207-218.

Jensen WA, 1962. Botanical Histochemistry. San Francisco: Freeman.

Kuo HL, Chen JT, dan Chang WC, 2005. Efficient Plant Regeneration Through Direct Somatic Embryogenesis from Leaf Explants of Phalaenopsis "Little Steve". In Vitro Cellular and Development Biology Plant. 41(4): 453-456.

Lee KS, Zapata-Arias, Brunner FJH, dan Afza R, 1997. Histology of Somatic Embryo Initiation and Organogenesis from Rhyzome Explants of Musa spp. Plant Cell, Tissue and Organ Culture. 51: 9-16.

Mamiya K, dan Sakamoto Y, 2001. A Method to Procedure Encapsulatable Units For Synthetic Seed in Asparagus officinalis. Plant Cell, Tissue and Organ Culture. 64: 27-32.

Merkle SA, Parrott WA, dan Williams EG, 1990. Applications of Somatic Embryogenesis and Embryo Cloning dalam Bhojwani SS. (Ed.) Plant Tissue Culture: Applications and Limitations Elsevier, Amsterdam, 67.

Nieves N, Martinez ME, Castillo L, Blanco MA, dan Olmedo JLG, 2001. Effect of Abscisic Acid and Jasmonic Acid on Partial Desiccation of Encapsulated Somatic Embryos of Sugarcane. Plant Cell, Tissue and Organ Culture. 65: 15-21.

Racuson RH, dan Schiavone FM, 1990. Positionalcues and Differential Gene Expression in Somatic Embryos of Higher Plants. Cell Diff Develop. 30: 159.

Sicurani ME, Piccioni A, dan Standardi, 2001. Micropropagation and Preparation of Synthetic Seed in M.26 Apple Rootstock I: Attempts towards Saving Labor in the Production of Adventitious Shoot Tips Suitable for Encapsulation. Plant Cell, Tissue and Organ Culture. 66: 207-216.

Steeves TA, dan Sussex IM, 1989. Patterns in Plant Development. $2^{\text {nd }}$ ed. Cambridge University Press; New York.

Taylor MG, dan Vasil IK, 1996. The Ultrastructure of Somatic Embryo Development in Pearl Millet (Pennisetum glaucum; Poaceae). American Journal of Botany. 83(1): 28-44.

Tokuhara K, dan Mii M, 2003. Highly-Efficient Somatic Embryogenesis from Cell Suspension Cultures of Phalaenopsis Orchids by Adjusting Carbohydrate Sources. In Vitro Cellular and Development Biology Plant. 39(6): 635-639.

Toonen MAJ, dan de Vries SC, 1996. Initiation of somatic embryos from single cells dalam Wang TL, dan Cuming A. (Ed.) Embryogenesis the generation of plant. Bios Scientific Publishers Limited. Oxford, 173-177.

Reviewer: Dr. Retno Mastutik 